\title{
EFFECT OF ENZYMATIC MODIFICATION ON THE BIOLOGICAL ACTIVITY AND NUTRITIVE VALUE OF COW AND BUFFALO CASEIN
}

\author{
S. HUSSEIN ${ }^{\mathrm{a}}$, É. GELENCSÉR ${ }^{\mathrm{a}}, \mathrm{M}$. POLGÁR ${ }^{\mathrm{b}}$ and GY. HAJÓS ${ }^{\mathrm{a}}$ \\ ${ }^{a}$ Central Food Research Institute, H-1022 Budapest, Herman O. út 15. Hungary \\ ${ }^{\mathrm{b}}$ Madarász Children Hospital, H-1131 Budapest, Madarász V. u. 22. Hungary \\ (Received: 13 March 2000; accepted: 31 March 2000)
}

\begin{abstract}
Buffalo and cow milk caseins were submitted to hydrolysis either with $\alpha$-chymotrypsin or with pepsin. Enzymatic peptide modification (EPM) was carried out by using L-methionine ethyl ester in the reaction mixture. As catalyst, $\alpha$-chymotrypsin or pepsin was used. The incorporation of methionine in to the peptide chains in the presence of $\alpha$-chymotrypsin showed an optimum value at $0.14 \mathrm{~g}$ Met added to the reaction mixture $/ 1 \mathrm{~g}$ hydrolysate in both cases. In the case of pepsin used as catalyst, the optimal Met-enrichment was at $0.14 \mathrm{~g}$ Met added to the reaction mixture $/ 1 \mathrm{~g}$ buffalo casein hydrolysate and at $0.34 \mathrm{~g}$ Met $/ 1 \mathrm{~g}$ cow casein hydrolysate.

The covalent nature of the amino acid incorporation was confirmed by SDS - polyacryl amide gel electrophoresis in the presence of urea. Electrophoretic patterns of the products indicate that transpeptidation plays an essential role in the EPM reaction. Antigenic character of the EPMproducts was investigated in vitro by competitive indirect ELISA.

Enzymatic peptide modification with methionine enrichment seems to be an efficient method for the reduction of the antigenic/potential allergenic character and for the improvement of the nutritive value of buffalo and cow milk caseins.
\end{abstract}

Keywords: enzymatic modification (EPM), Met-enrichment, potential allergenic character, biological activity

Several investigators have evaluated the immunogenicity and/or allergenicity of enzymatically hydrolysed casein for potential use in infant formulae (TAKASA et al., 1979, OTANI et al., 1990, NAKAMURA et al., 1993) and whey proteins (ASSELIN et al., $1988,1989)$ by using different techniques.

WHITAKER and PUIGSERVER (1982) reported that enzymatic modification of food proteins was a suitable method for designed amino acid incorporation and structure modification of the protein chains.

An experimental proof of transpeptidation in the course of enzymatic modification of milk proteins (WHITAKER \& PUIGSERVER, 1982, HAJós, 1986, 1996) has also been published. This enzymatic process allows enrichment of the proteolysis 
products of casein with essential amino acids (HAJós et al., 1988, 1990, LORENZEN \& SCHLIMME, 1992) which are terminally bound to the peptides in a covalent manner.

Our earlier results showed that the enzymatic peptide modification (EPM) is an appropriate process for the reduction of the allergenic character of proteins (GELENCSÉR et al., 1992, POLGÁr et al., 1996, 1998) and for the improvement of the biological value by incorporation of a limiting essential amino acids into the milk and soy protein chains (Hussein et al., 1996, Hussein \& HAJós, 1993, Hajós et al., 1993, 1997, SÜLE et al., 1998).

The aim of our study was to reduce the allergenic character and to improve the methionine content of buffalo (HEwEDY et. al., 1989) and cow milk caseins.

\section{Materials and methods}

\subsection{Preparation of whole buffalo and cow milk caseins}

Casein was precipitated from unpasteurized cow or buffalo skim milk by acidification to $\mathrm{pH} 4.6$ through the slow addition of $1 N \mathrm{HCl}$. The precipitate was separated by filtering the solution through cheesecloth. After being washed with distilled water, the precipitate was redissolved by slowly adding $1 \mathrm{~N} \mathrm{NaOH}$ to a final solution $\mathrm{pH}$ of 7.0. This precipitation, washing and neutralization was repeated three times, and the casein solution ( $\mathrm{pH} 7.0$ ) was lyophilized and stored at $-20^{\circ} \mathrm{C}$ until use.

\subsection{Preparation of protein hydrolysates}

1.2.1. Hydrolysates of buffalo casein. Buffalo casein was hydrolysed with $\alpha$ chymotrypsin at $\mathrm{pH} 7.5$, or with pepsin at $\mathrm{pH}$ 2.0. (The enzyme:protein ratio was $1: 100 \mathrm{w} / \mathrm{w}$ ). The incubation was carried out at $37{ }^{\circ} \mathrm{C}$ for $2 \mathrm{~h}$. The reaction mixture was stirred during hydrolysis and after that freeze-dried.

1.2.2. Hydrolysates of cow casein. Cow casein was hydrolysed with $\alpha-$ chymotrypsin, enzyme:protein ratio: $1: 100(\mathrm{w} / \mathrm{w})$, at $\mathrm{pH} 7.5$, or with pepsin at $\mathrm{pH} 2.0$ and incubated as above.

\subsection{Enzymatic peptide modification}

Buffalo and cow caseins hydrolysed with $\alpha$-chymotrypsin or pepsin were used at the substrate (hydrolysate) concentration of $25 \%$ to produce EPM products in the presence of $\alpha$-chymotrypsin at $\mathrm{pH} 6.0$ or pepsin at $\mathrm{pH} 4.0$, as catalysts. The protein: enzyme ratio was $100: 1 \mathrm{w} / \mathrm{w}$. 
Table 1

Methionine concentration in the reaction mixture

\begin{tabular}{lcc}
\hline Samples & $\begin{array}{c}\text { Methionine added } \\
\left(\mathrm{g}^{-1} \mathrm{~g} \text { hydrolysate }\right)\end{array}$ & $\begin{array}{c}\text { L-methionine ethyl } \\
\text { ester added } \\
\left(\mathrm{g}^{-1} \mathrm{~g} \text { hydrolysate }\right)\end{array}$ \\
\hline EPM 0 & 0.00 & 0.000 \\
EPM 2 & 0.14 & 0.210 \\
EPM 4 & 0.34 & 0.487 \\
EPM 6 & 0.48 & 0.697 \\
EPM 8 & 0.63 & 0.902 \\
EPM 10 & 0.91 & 1.317 \\
\hline
\end{tabular}

Methionine in the form of L-methionine ethyl ester was added to the protein hydrolysate (see Table 1.). The EPM products were, after $16 \mathrm{~h}$ of incubation at $37^{\circ} \mathrm{C}$, simultaneously dialyzed for $48 \mathrm{~h}$ through a cellophane membrane against distilled water. The non-dialyzable fraction was freeze-dried.

\subsection{SDS-PAGE}

Polyacrylamide gel electrophoresis in the presence of sodium dodecyl sulphate (SDS) was carried out using 10\% polyacrylamide gels (bisacrylamide-acrylamide, 1:37) containing $0.1 \mathrm{~mol}$ sodium phosphate buffer $\mathrm{pH} 7.2,0.1 \%$ SDS and $6 \mathrm{~mol}$ urea. The electrophoresis buffer consisted of 0.1 mol sodium phosphate, $0.1 \%$ SDS, pH 7.2 and the sample buffer was $0.01 \mathrm{~mol}$ sodium phosphate, $1 \%$ SDS, $2 \% \beta$-mercapto ethanol, $\mathrm{pH}$ 7.2. Samples were heated in the sample buffer for $2 \mathrm{~min}$ at $100{ }^{\circ} \mathrm{C}$, cooled and $6 \mathrm{~mol}$ urea was added. Electrophoresis conditions were $50 \mathrm{~V}$ for $1 \mathrm{~h}$, followed by $100 \mathrm{~V}$ for about 4-5 h. Protein staining was carried out by Coomassie Brillant Blue R-250, involving the use of formaldehyde fixation to avoid losses of low molecular weight peptides. A more sensitive staining was achieved by the silver staining procedure.

\subsection{Amino acid content}

An aliquot of the samples was hydrolysed with $6 \mathrm{~mol} \mathrm{HCl}$ in a tube flushed with $\mathrm{N}_{2}$ at $105{ }^{\circ} \mathrm{C}$ for $24 \mathrm{~h}$ and the amino acids were separated by thin layer ion exchange chromatography. The amino acids were developed with an acetone ninhydrin reagent by heating at $70{ }^{\circ} \mathrm{C}$ for $10 \mathrm{~min}$.

In situ quantitative evaluation of the methionine spot on this chromatographic layer was carried out by Biotech-Fischer densitometer (identified and compared to the control methionine). 


\subsection{N-terminal amino acids of the peptides}

Leucine aminopeptidase (LAP) treatment. A suspension of the EPM-product $(5 \mathrm{mg})$ was incubated with LAP in $100 \mu \mathrm{l} 0.1 \mathrm{~mol} \mathrm{NH}_{4} \mathrm{HCO}_{3}$ buffer. Samples $(10 \mu \mathrm{l})$ were investigated after incubating for $0,10,30$ and $60 \mathrm{~min}$, respectively, at which times each sample was immediately mixed with an equal volume of concentrated $\mathrm{HCl}$ to stop the enzyme reaction.

\subsection{C-terminal amino acids}

Carboxypeptidase treatment. The samples were incubated with a mixture (1:1) of carboxypeptidase A $\left(50 \mathrm{U} \mathrm{mg}^{-1}\right)$ and carboxypeptidase $\mathrm{B}\left(50 \mathrm{U} \mathrm{mg}^{-1}\right)$. The treatment and the amino acid determination were the same as in the leucine aminopeptidase treatment.

\subsection{ELISA test}

The potential allergenic character of the samples was measured in vitro by competitive indirect ELISA test (GELENCSÉR et al., 1992).

Buffalo or cow milk protein antigen was coated on the assay wells by incubating $100 \mu \mathrm{l} /$ well of protein at $5 \mu \mathrm{g} \mathrm{ml}^{-1}$ in carbonate buffer, $\mathrm{pH} 9.4$ for overnight at $4{ }^{\circ} \mathrm{C}$. Between each step, the plates were washed three times with phosphate-buffered saline (PBS), pH 7.4, 0.1 mol containing $0.5 \%$ Tween 20 . Free binding sites were blocked by incubation of wells with $200 \mu \mathrm{l} /$ well of PBS buffer, pH 7.4 containing $0.5 \%$ gelatine. The wells were then incubated by $50 \mu 1 /$ well primary antibodies (human sera containing specific IgG antibodies to milk protein antigens, purchased from the Gastroenterological Center of Madarász Children's Hospital, Hungary) at working dilution (1:160) in PBS buffer $\mathrm{pH} 7.4$ and by $50 \mu \mathrm{l} /$ well of competitive antigens (EPM products) at concentrations $10^{-3} \mu \mathrm{g} \mathrm{ml}^{-1}-10^{3} \mu \mathrm{g} \mathrm{ml}^{-1}$ in PBS buffer, $\mathrm{pH} 7.4$ for $1 \mathrm{~h}$ at $37^{\circ} \mathrm{C}$. The bound antigen specific IgG concentrations were detected with HRP-labelled goat-Iganti-human IgG conjugate (HUMAN, Hungary) by incubating $100 \mu \mathrm{l} /$ well conjugate at working dilution (1:160) in PBS buffer $\mathrm{pH} 7.4$ for $1 \mathrm{~h}$ at $37^{\circ} \mathrm{C}$. The HRP-activity was measured in $100 \mu \mathrm{l} /$ well sodium citrate substrate solution, containing $10 \mu \mathrm{l}$ of $30 \%$ (w/v) $\mathrm{H}_{2} \mathrm{O}_{2}$. After incubation for $30 \mathrm{~min}$ with substrate solution at room temperature the reaction was stopped by adding $50 \mu \mathrm{l} / \mathrm{well}$ of $4 \mathrm{~mol} \mathrm{H}_{2} \mathrm{SO}_{4}$ solution, and the optical density was measured in a titer-tek Multiscan (Flow, UK) at $492 \mathrm{~nm}$. Results were expressed in \%, by reference to a standard serum. 
1.9. Allergenic character

$$
A(\%)=\left(1-\frac{A_{i}-A_{b l}}{A_{s t}-A_{b l}}\right) \times 100
$$

where

$A$ : allergenic activity of samples involved in the inhibition assays

$A_{i}$ : absorbance of the samples at $492 \mathrm{~nm}$

$A_{b l}$ : absorbance of the blank solution at $492 \mathrm{~nm}$

$A_{\text {st }}$ : absorbance of the standard serum at $492 \mathrm{~nm}$.

\section{Results and discussion}

\subsection{Electrophoretic patterns of the EPM products of buffalo and cow caseins}

The electrophoretic patterns of protein fractions of the buffalo casein, buffalo casein hydrolysate with $\alpha$-chymotrypsin and EPM products separated with SDS-PAGE are shown in Fig. 1. These results illustrate that buffalo caseins contain four zones ranging from 30000 to $80000 \mathrm{~mol}$. mass. Hydrolysis of buffalo casein with $\alpha$-chymtorypsin degraded the major casein fractions (30000 and 17000 mol.mass) and produced four new fractions ranging from 14000 to 2500 mol.mass.

The principal protein zones in EPM products were similar in number and relative mobilities of the zones of casein hydrolysate.

From electrophoretograms presented in Fig. 1, it can be seen that the difference between EPM 0 and EPM 4, where the intensity of fraction was 6000 mol.mass, increased. Fig. 1 shows that the differences between EPM 6 and EPM 10 marked the greatest intensity of staining in the mol.mass of about 6000 . Generally, these changes of the molecular mass and intensity were essentially influenced by the concentration of L-methionine ethyl ester in the reaction mixture.

The electrophoretic patterns of protein fractions of the cow milk protein, hydrolysate with $\alpha$-chymotrypsin and EPM products separated by SDS-PAGE are shown in Fig. 2. The $\alpha$-chymotrypsin hydrolysation caused a complete loss of $\alpha$ - and $\beta$ caseins. The substrate for enzymatic modification (Sample 4) showed 4 fractions at the lowest intensity in the molecular range of about 17000 to as small as 2500 mol. mass. From Fig. 2, it can be seen that the molecular weights and intensity of EPM products were higher than those of the hydrolysate. It can also be seen that zone intensity of EPM products increased by rising the concentration of L-methionine ethyl ester in the reaction mixture. 


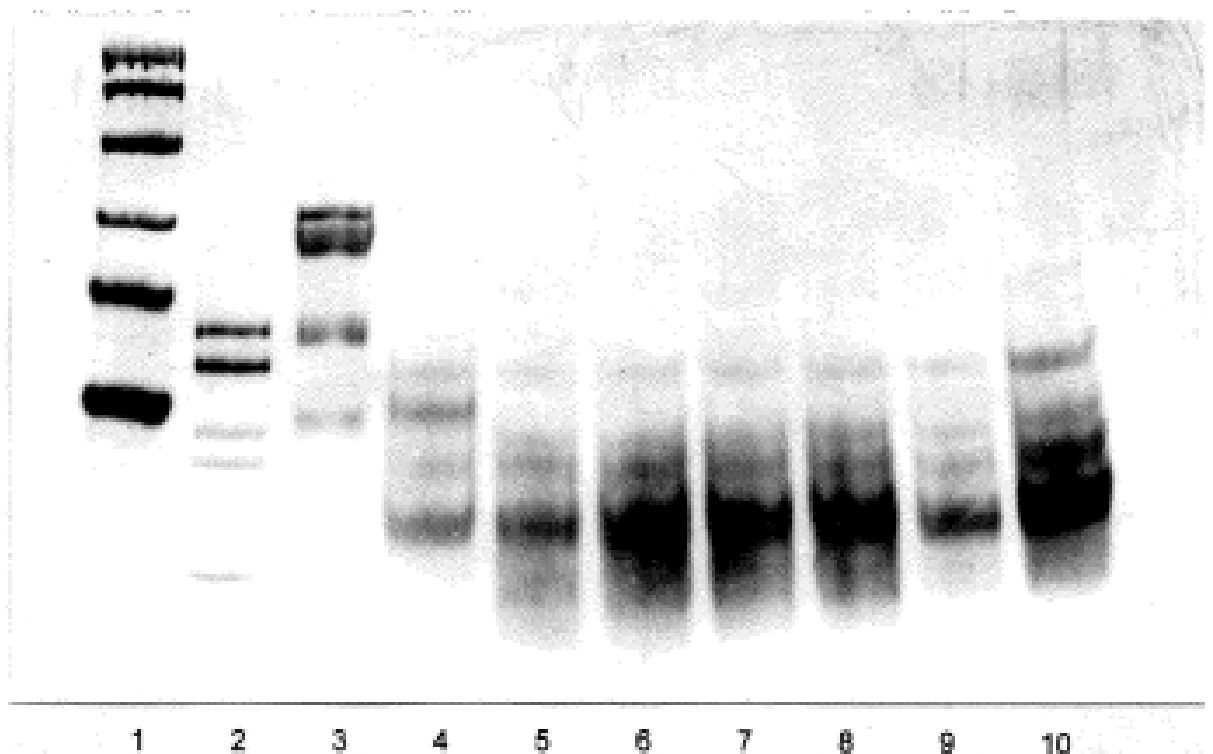

Fig. 1. SDS-PAGE patterns of the buffalo casein, its $\alpha$-chymotryptic hydrolysate and EPM-products. 1: low molecular weight protein standard from Sigma (LMW: 94000, 67000, 43000, 30000, 20000, 14400);

2: low molecular weight peptide standard (PMW: 17200, 14600, 8290, 6380, 2560); 3: buffalo casein; 4: $\alpha$-chymotryptic hydrolysate of buffalo casein; 5: EPM product without amino acid enrichment; 6-10: EPM products ( $\alpha$-chymotrypsin used as catalyst) with different Met-enrichments. For conditions see Materials and methods

The changes in the zones indicate that transpeptidation was the major process in the enzymatic modification.

Figures 3 and 4 show the effect of pepsin on buffalo and cow caseins to hydrolysis and catalyst of the modified protein products.

Figure 4 shows that the intensity of zones in the range of 6000-30000 mol.mass of EPM products gradually increased by rising the concentration of methionine ethyl ester in the reaction mixture. 


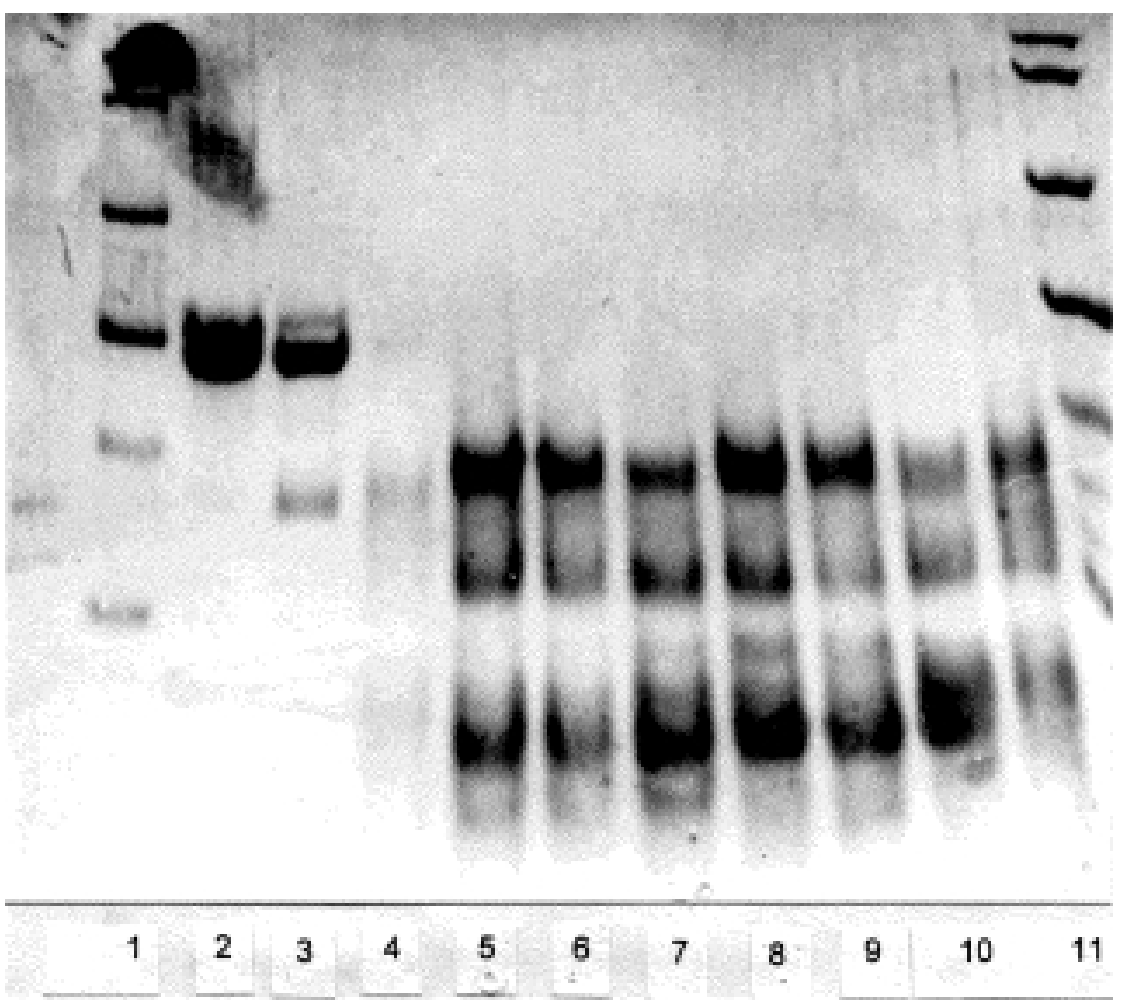

Fig. 2. SDS-PAGE patterns of the cow casein, its $\alpha$-chymotryptic hydrolysate and EPM-products. 1 and 11: low molecular weight protein standard from Sigma (LMW: 94000, 67000, 43000, 30000, 20000, 14400); 3: cow casein; 4: $\alpha$-chymotryptic hydrolysate of cow casein; 5 : EPM product without amino acid enrichment; $6-10$ : EPM products ( $\alpha$-chymotrypsin used as catalyst) with different Met-enrichments. For conditions see Materials and methods

\subsection{Incorporation of L-methionine into buffalo and cow casein hydrolysates by enzymatic modification}

Table 2 shows the methionine content of buffalo and cow casein hydrolysates and EPM products when $\alpha$-chymotrypsin was used as catalyst. This comparison show that methionine contents in the EPM products with methionine incorporation were found to be higher than that of the substrate protein. The results displayed that methionine content of EPM products from cow casein was higher than that of the EPM products from buffalo casein. 
The optimum of L-methionine incorporation in the case of cow casein and buffalo casein (EPM 2) was found at a ratio of $14 \mathrm{~g} \mathrm{Met} / 100 \mathrm{~g}$ hydrolysate in this enzyme process. Methionine content of EPM 2 in the case of cow casein is higher by $2.7 \%$ than that of EPM 0, but in the case of buffalo casein it is higher by $1.5 \%$. Also methionine content of EPM 2 in the case of cow casein is higher by $1.5 \%$ than that of EPM 2 in the case of buffalo casein.

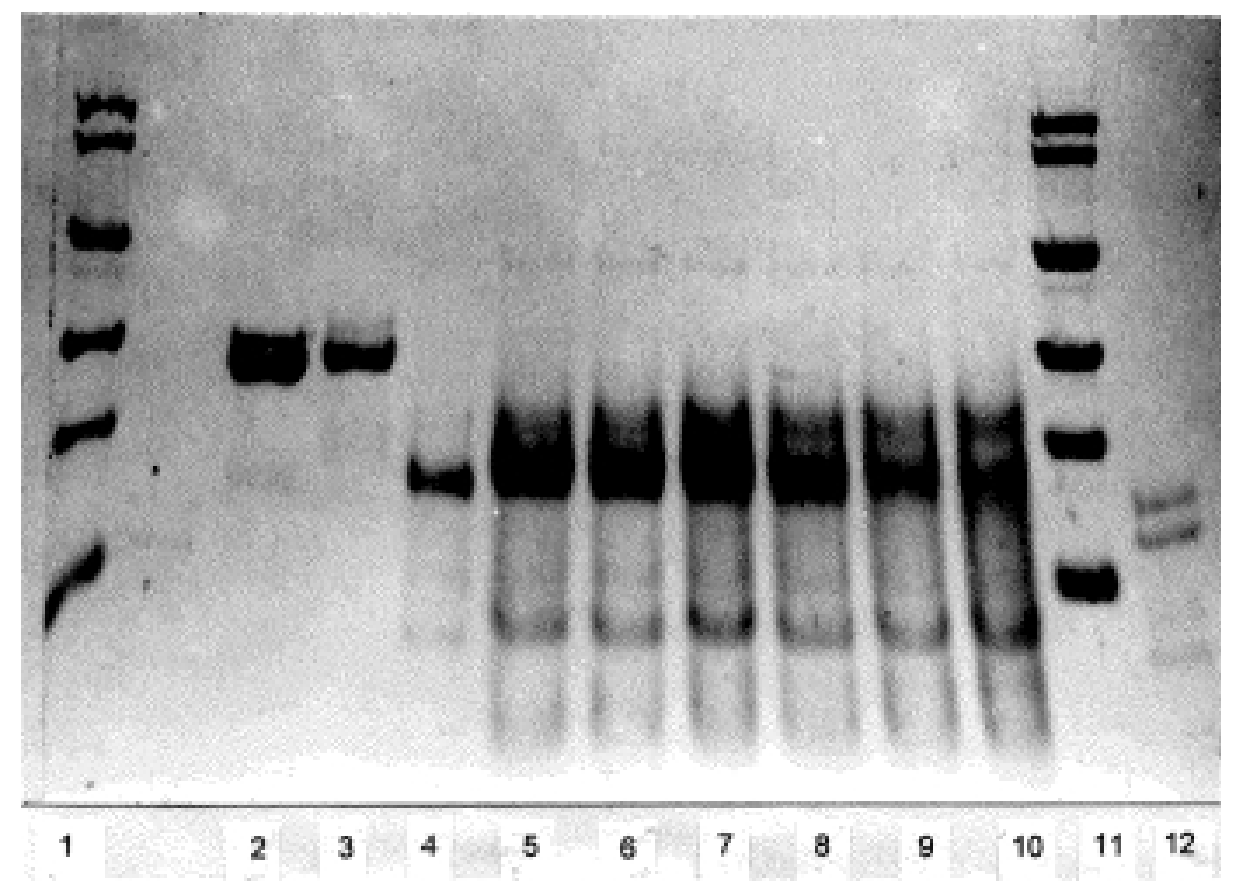

Fig. 3. SDS-PAGE patterns of the buffalo casein, its peptic hydrolysate and EPM-products. 1 and 11: low molecular weight protein standard from Sigma (LMW: 94000, 67000, 43000, 30000, 20000, 14400); 2, 3: buffalo caseins; 4: peptic hydrolysate of buffalo casein; 5: EPM product without amino acid enrichment; 6-10: EPM products (pepsin used as catalyst) with different Met-enrichments. 12: low molecular weight peptide standard (PMW: 17200, 14600, 8290, 6380, 2560). For conditions see Materials and methods 


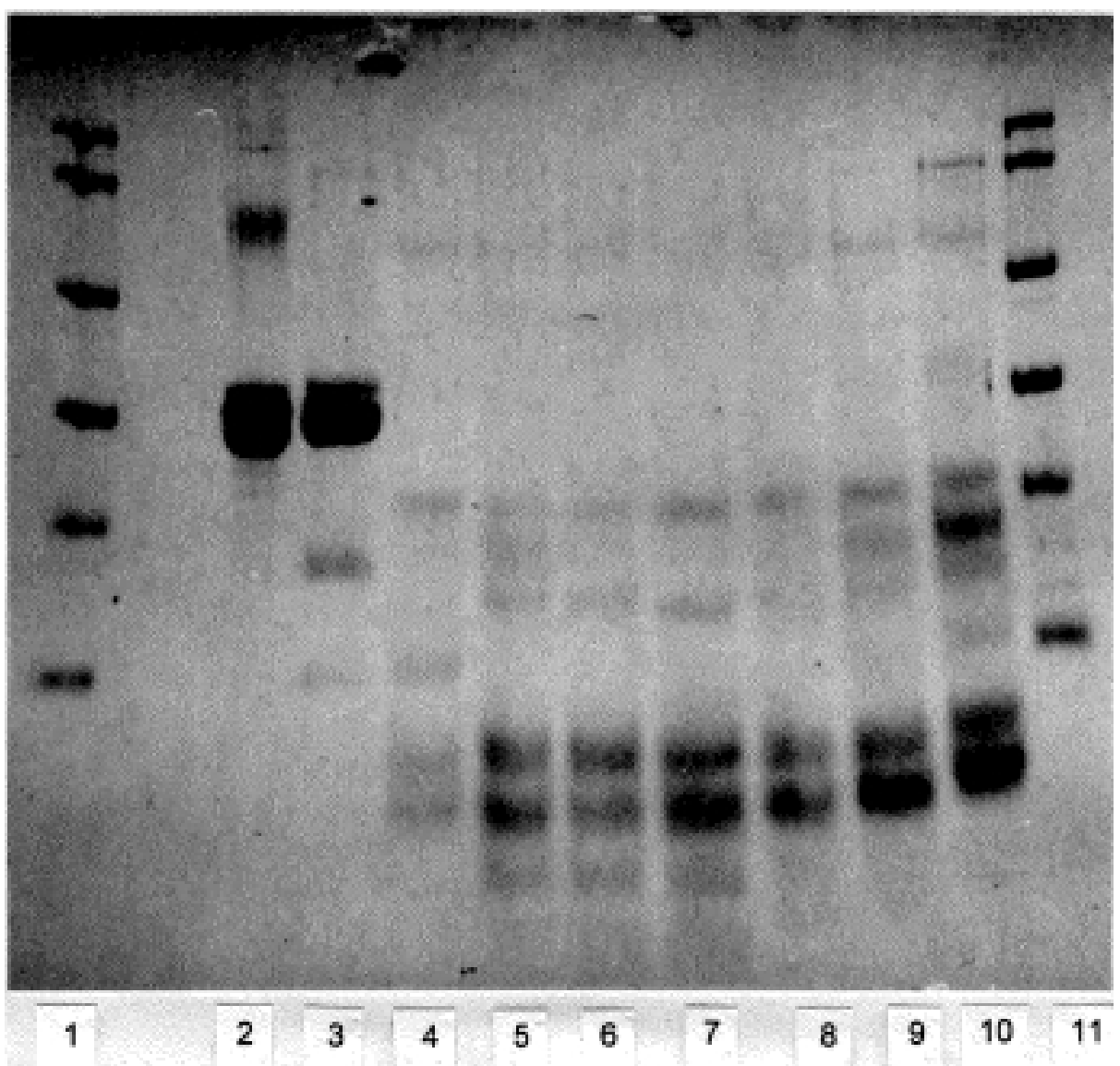

Fig. 4. SDS-PAGE patterns of the cow casein, its peptic hydrolysate and EPM-products. 1 and 11: low molecular weight protein standard from Sigma (LMW: 94000, 67000, 43000, 30000, 20000, 14400); 2: buffalo casein; 3: cow casein; 4: peptic hydrolysate of cow casein; 5: EPM product without amino acid enrichment; 6-10: EPM products (pepsin used as catalyst) with different Met-enrichments. For conditions see Materials and methods

Methionine content of buffalo and cow casein hydrolysates and EPM products catalyzed with pepsin are shown in Table 3. The optimum of L-methionine incorporation when pepsin was used as catalyst in the case of cow casein (EPM 4), was found at a ratio of $34 \mathrm{~g} \mathrm{~L}-\mathrm{Met} / 100 \mathrm{~g}$ hydrolysate, but in the case of buffalo casein (EPM 2) this optimum was seen at a ratio of $14 \mathrm{~g} \mathrm{~L}-\mathrm{Met} / 100 \mathrm{~g}$ hydrolysate. 
Table 2

Methionine content of the modified buffalo and cow casein, $\alpha$-chymotrypsin used as catalyst

\begin{tabular}{lcc}
\hline \multirow{2}{*}{ Samples } & \multicolumn{2}{c}{$\begin{array}{c}\text { Methionine covalently bound } \\
\text { (g Met/100 g protein) }\end{array}$} \\
\cline { 2 - 3 } & buffalo casein & cow casein \\
\hline EPM 0 & 1.3 & 1.6 \\
EPM 2 & 2.8 & 4.3 \\
EPM 4 & 2.1 & 3.0 \\
EPM 6 & 1.9 & 3.45 \\
EPM 8 & 1.6 & 3.75 \\
EPM 10 & 1.3 & 2.7 \\
\hline
\end{tabular}

Table 3

Methionine content of the modified buffalo and cow casein, pepsin used as catalyst

\begin{tabular}{lcc}
\hline \multirow{2}{*}{$\begin{array}{c}\text { EPM } \\
\text { samples }^{\mathrm{a}}\end{array}$} & \multicolumn{2}{c}{$\begin{array}{c}\text { Methionine covalently bound } \\
\text { (g Met/100 g protein) }\end{array}$} \\
\cline { 2 - 3 } & buffalo casein & cow casein \\
\hline EPM O & 1.5 & 1.4 \\
EPM 2 & 2.6 & 2.5 \\
EPM 4 & 2.2 & 3.0 \\
EPM 6 & 1.8 & 1.9 \\
EPM 8 & 1.6 & 1.7 \\
EPM 10 & 1.3 & 1.7 \\
\hline
\end{tabular}

${ }^{a}$ See Table 1 for Met added to hydrolysate

The results revealed that the amount of methionine incorporated changed with the type of the casein and enzyme applied.

In case of buffalo casein, the higher the amount of methionine ethyl ester added to the reaction mixture, the lower amount of covalently bound methionine was found in the products. A possible interpretation of this surprising contradiction is that the changes in the ratio between methionine ethyl ester and protein hydrolysate influence the degree of the amino acid incorporation and thereby the primary structure of the products and, consequently, the functionality of the proteins.

Generally, when $\alpha$-chymotrypsin was used as catalyst, the amount of methionine incorporated was higher compared to pepsin catalyzation. The results also revealed that the amount of methionine incorporated in the case of cow casein was higher than in the case of buffalo casein. 
The effects of exopeptidases on buffalo casein hydrolysate and EPM product are shown in Fig. 5. In samples taken at zero time, where $\mathrm{HCl}$ was added together with exopeptidase to prevent digestion, no free amino acid was present. In Fig. 5 it can be seen that methionine was present in the EPM product, while it was absent in the buffalo casein hydrolysate.

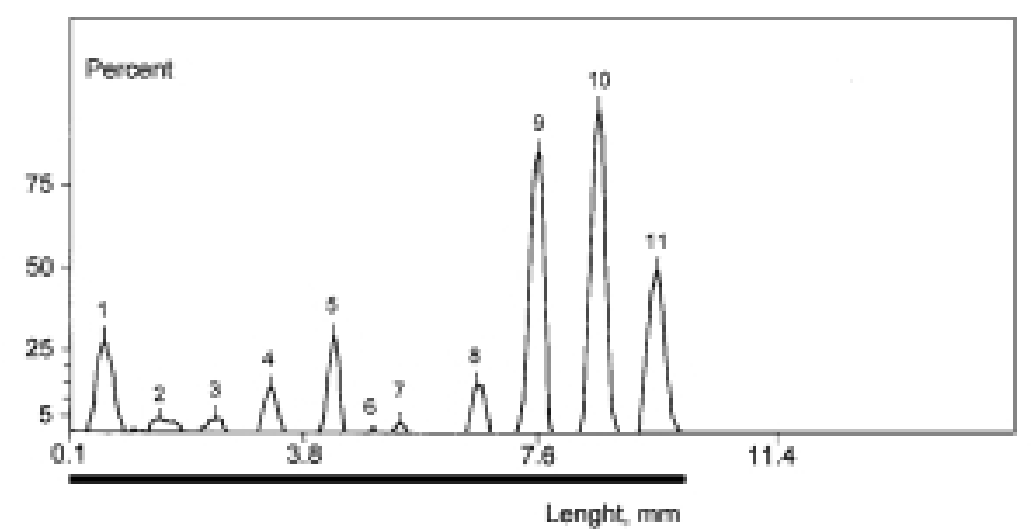

Fig. 5. Densitometric evaluation of the liberated methionine from $\alpha$-chymotryptic hydrolysate and EPM product of buffalo casein treated with carboxipeptidase $(A+B)$. Thin layer ion exchange chromatography was used for separation of the liberated amino acids during exopeptidase treatment, 1 and 11: control methionine; 2-5: samples of hydrolysate obtained after $0,10,30$ and $60 \mathrm{~min}$ carboxipeptidase treatment respectively; 6-10: samples of EPM product with Met-enrichment obtained after 0, 10, 30, and $60 \mathrm{~min}$ carboxipeptidase treatment, respectively. For conditions see Materials and methods

In the case of EPM product, samples obtained after $10 \mathrm{~min}$ to $60 \mathrm{~min}$, increasing amounts of L-methionine could be detected as a result of exopeptidase action. Figure 5 and Table 4 show that the amount of free L-methionine after $60 \mathrm{~min}$ was seven times the amount of free L-methionine found after $10 \mathrm{~min}$. As methionine is preferently bound to the C-terminal end of the peptide, carboxypeptidase could be an efficient catalyst for amino acid incorporation by enzymatic process. On the other hand, with LAP treatment no significant amount of methionine existed at $\mathrm{N}$-terminals of the EPM molecules.

These results suggest that enzymatic peptide modification is a suitable method for increasing the nutritive value of buffalo and cow caseins by the incorporation of a given quantity of a particular limiting essential amino acid. 
Table 4

Semi-quantitative evaluation of methionine content in the samples separated by thin layer ion exchange chromatography

\begin{tabular}{rrrrr}
\hline Number & $\begin{array}{c}\text { Position } \\
(\mathrm{mm})\end{array}$ & $\begin{array}{c}\text { Area } \\
(\text { pixel })\end{array}$ & $\begin{array}{c}\text { Height } \\
(\%)\end{array}$ & $\begin{array}{c}\text { \% area } \\
(\%)\end{array}$ \\
\hline 1 & 0.5405 & 1053 & 28.2 & 9.4 \\
2 & 1.4553 & 221 & 4.7 & 2.0 \\
3 & 2.3909 & 156 & 4.7 & 1.4 \\
4 & 3.2848 & 393 & 13.3 & 3.5 \\
5 & 4.3243 & 811 & 29.8 & 7.2 \\
6 & 5.3846 & 47 & 2.7 & 0.4 \\
7 & 5.5509 & 39 & 2.0 & 0.3 \\
8 & 6.6320 & 425 & 14.5 & 3.8 \\
9 & 7.6091 & 2758 & 85.5 & 24.6 \\
10 & 8.5863 & 3401 & 97.6 & 30.3 \\
11 & 9.5218 & 1918 & 49.8 & 17.1 \\
\end{tabular}

Buffalo casein hydrolysate and EPM product treated with carboxypeptidase $(A+B)$, investigated after incubating for $0.10,30$ and $60 \mathrm{~min}$, respectively.

$1,11 \quad$ control

2, 3, 4, 5 samples obtained from buffalo casein hydrolysate after $0,10,30$ and 60 min, respectively

$6+7,8,9,10 \quad$ samples obtained from EPM product after 0, 10, 30 and 60 min, respectively

\subsection{Reduction of the allergenicity of buffalo casein and cow casein by enzyme modification}

Allergenic character of cow and buffalo milk casein and EPM modified casein were investigated. Allergenic character of the Met-enriched, EPM-modified buffalo casein samples were compared to that of the untreated casein and buffalo casein hydrolysate with $\alpha$-chymotrypsin (Fig. 6).

The samples of this EPM series contained different methionine concentrations (in the form of Met ethylester) in the reaction mixture. Fig. 6 shows that the reduction of the allergenic character of the modified buffalo casein is significantly improved by the increase of the concentration of Met ester in the reaction mixtures. The hydrolysis of buffalo casein with $\alpha$-chymotrypsin eliminated about $15 \%$ of total allergenic activity. There were little differences between casein hydrolysate and the sample EPM 0 (without methionine), and the samples of EPM 2, 4, 6 where the Met concentration was $82.3 \%$, $80 \%, 72.8 \%$ in the reaction mixtures, respectively. The biggest difference was, however, between the samples EPM 8, EPM 10 and the casein hydrolysate. 


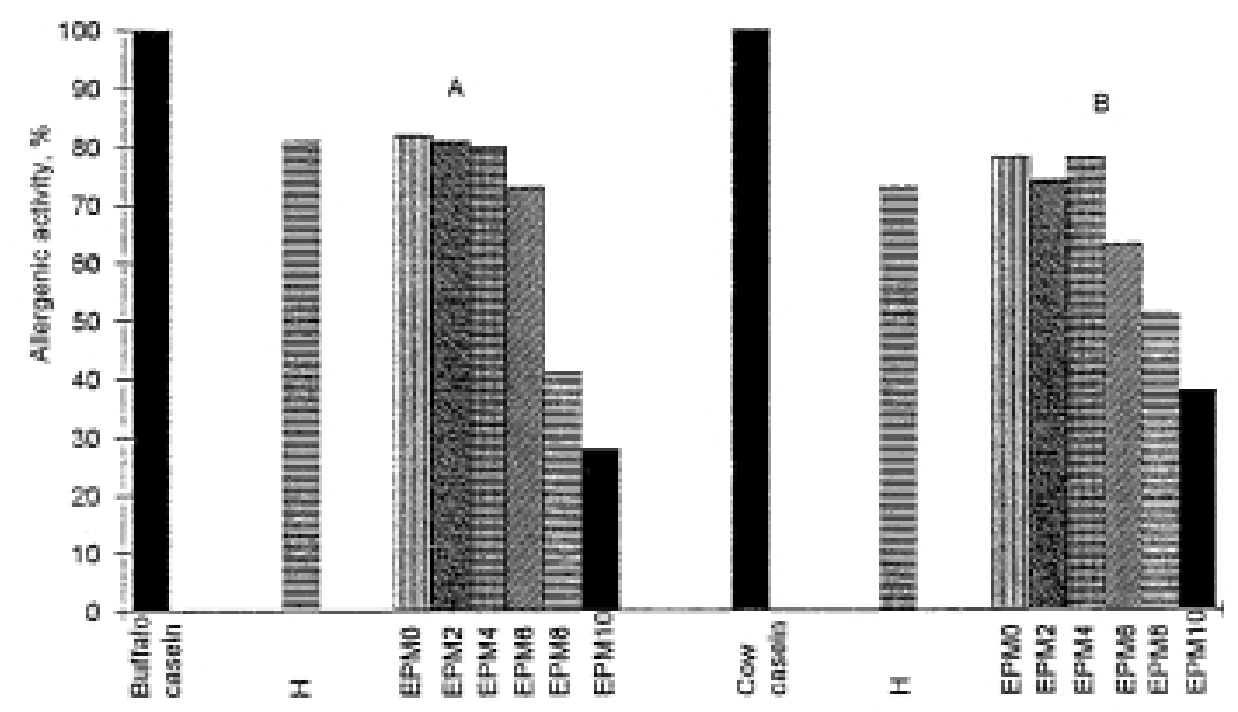

Fig. 6. Potential allergenic character of the enzymatically modified buffalo and cow casein products. A: $\alpha-$ chymotryptic hydrolysate of buffalo casein and EPM products in the presence of $\alpha$-chymotrypsin as catalyst; B: $\alpha$-chymotryptic hydrolysate of cow casein EPM products in the presence of $\alpha$-chymotrypsin as catalyst; EPM 0: EPM product without amino acid enrichment; EPM 2 - EPM 10: EPM products with different methionine enrichment (see Table 1); H: hydrolysate

The allergenic character of cow milk casein, cow milk casein hydrolysate, its EPM products with and without methionine enrichment was also investigated (Fig. 6). Little differences were found between both cow casein and buffalo casein hydrolysates with $\alpha$-chymotrypsin, and they revealed the same trend of decrease in allergenic activity. The decreased allergenic activity of EPM products may be due to transpeptidation processes in the course of EPM.

Figure 7 shows the allergenic activity of cow casein and buffalo casein hydrolysates with pepsin and EPM products in the presence of different methionine ethyl ester concentrations in the reaction mixture. The results showed that both hydrolysates were characterized by low allergenic activity, but cow casein hydrolysate was very low in comparison to buffalo casein hydrolysate, $30 \%$ and $16 \%$, respectively. The results showed also that the allergenic activities of both EPM products were very low and were not affected by the concentration of methionine ethyl ester in the reaction mixture. 


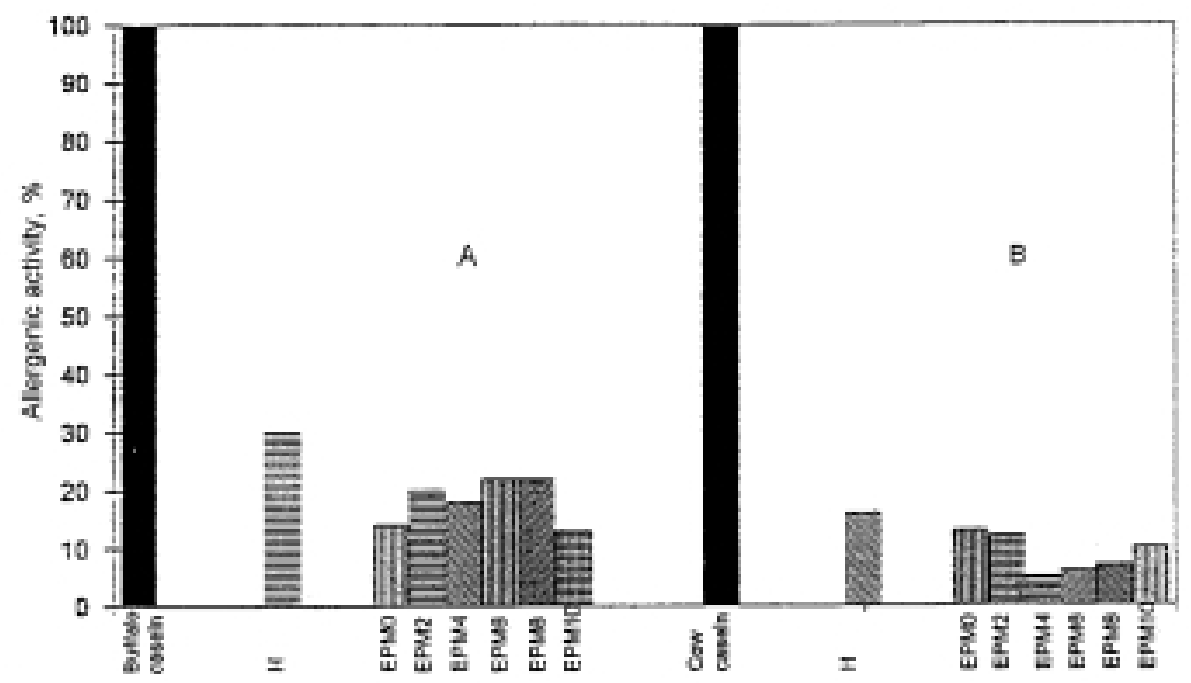

Fig. 7. Potential allergenic character of the enzymatically modified buffalo and cow casein products. A: peptic hydrolysate of buffalo casein and EPM products in the presence of pepsin as catalyst; B: peptic hydrolysate of cow casein and EPM products in the presence of pepsin as catalyst; EPM 0: EPM product without amino acid enrichment; EPM 2 - EPM 10: EPM products with different methionine enrichment (see Table 1); H: hydrolysate

The change of the allergenic character of the EPM samples of buffalo and cow caseins showed fairly curious results. The higher the amount of menthionine ehtyl ester added to the reaction mixture, the lower the level of the allergenic character detected.

The allergenicity of the enzyme hydrolysed products significantly decreased in comparison to the untreated caseins, presumably because of the cleavage of a great number of peptide bonds. The fact that the allergenic character of proteins could be decreased by this enzyme-catalyzed method was due, very probably, to two different factors: the transpeptidation and the amino acid enrichment of the modified peptides.

This work was supported by the Hungarian Research Fund: OTKA T 029367. 


\section{References}

ASSElin, J., Amiot, J., GAUThIER, S. F., MOURAD, W. \& HeBERT, J. (1988): Immunogenicity and allergenicity of whey protein hydrolysates. J. Fd Sci., 53, 1208-1211.

ASSELIN, J., HEBERT, J. \& AMIOT, J. (1989): Effect of in vitro proteolysis on the allergenicity on major whey proteins. J. Fd Sci., 54, 1037-1039.

GELENCSÉR, É., POlgÁR, M. \& HAJÓS, GY. (1992): Screening of food protein allergy in childhood by an allergen-specific IgG-ELISA test. -in: Biochemistry of disease. Abstract of the first IUBM Conference Nagoya, Japan, pp. 6-9.

HAJós, GY. (1986): Incorporation of essential amino acids into protein by enzymatic peptide modification (EPM). Nahrung, 30, 418-419.

HAJÓS, GY. (1996): Enzymatic modification as a tool for alteration of safety and quality of food proteins. -in: MAGDASSI, S. (Ed.) Surface activity of proteins: chemical and physicochemical modifications. Marcel Dekkel Inc., New York, pp. 131-180.

HAJóS, GY., ÉLIÁS, I. \& HALÁSZ, A. (1988): Methionine enrichment of milk protein by enzymatic peptide modification. J. Fd Sci., 53, 739-742.

HAJÓS, GY., SZARVAS, F. \& VÁMOS-ViGYÁZÓ, L. (1990): Radioactive methionine incorporation into peptide chains by enzymatic modification. J. Fd Biochem., 24, 381-394.

HAJÓS, Gy., HuSSEIN, S. \& GELENCSÉR, É. (1993): Enzymatic peptide modification of food proteins. -in: SCHWENKE, K. D., MOTHER, R. (Eds) Food proteins, structure and functionality. VCH, Weinheim, pp. 82-86.

Hajós, Gy., SZERDAhEly, E., GelencSÉR, É. \& POlgÁR, M. (1997): Antigenic character and protein structure. Acta Alimentaria, 26, 294-295.

HewEDY, M. M., NASSiB, T., A., ZIN El-DiN, H., M. \& EL-SAKKARY, E. S. (1989): Studies on buffalo casein. I. Composition of casein micelles. Egyptian J. Dairy Sci., 17, 87-92.

HUSSEIN, S. \& HAJÓS, GY. (1993): Enzymatic modification of buffalo milk proteins. Acta Alimentaria, 22 , $351-358$

HuSSEIN, S., GELENCSÉR, É. \& HAJÓS, GY. (1996): Reduction of allergenicity and increasing the biological value of buffalo's milk proteins by enzymatic modification of $J$. Fd Biochem., 19, 239-252.

LORENZEN, P. C. \& SCHLIMME, E. (1992): The plastein reaction, properties in comparison with simple proteolysis. Milchwissenschaft, 47, 499-504.

NAKAMURA, T., SYUKUNOBE, Y., SAKURAI, T. \& IDOTA, T. (1993): Enzymatic production of hypoallergenic peptide from casein. Milchwissenschaft, 48, 11-14.

OTANI, H., DONG, X. Y. \& HoSONO, A. (1990): Preparation of low immunogenic peptide fragments from cow milk casein. Milchwissenschaft, 45, 217-220.

POLGÁR, M., GELENCSÉR, É. \& HAJÓS, GY. (1996): Keresztallergia vizsgálata tehéntej allergia esetében. (Investigation of cross allergy in the case of cow's milk allergy). Gyermekgyógyászat, 47, 91-97.

POlgÁR, M., HAJós, GY. \& GElenCSÉR, É. (1998): Alergia cruzada. (Cross-allergy.) Pediatria Integral, 3 , 208-217.

SÜle, E., ShIN, W. S., PARK, D-J., HAJós, GY. \& KwON, D. Y. (1998): Changes of $\alpha$-chymotrypsin during enzymatic peptide modification. Acta Alimentaria, 27, 181-191.

TAKaSA, M., FuKuWATARI, Y., KaWASE, K., KoyosaWA, I., OgaSA, K., SuZUKI, S. \& KuROUME, T. (1979): Antigenicity of casein enzymatic hydrolysate. J. Dairy Sci., 62, 1570-1576.

WHITAKeR, J. R. \& PUIGSERVER, A. J. (1982): Fundamentals and application of enzymatic modifications of proteins: an overview. Adv. Chem. Ser., 198, 57-87. 